\section{W.E.UPJOHN \\ INSTITUTE \\ FOR EMPLOYMENT RESEARCH}

\section{Employment Research Newsletter}

$10-1-2001$

\title{
Risk Sharing through Social Security Retirement Income Systems: A Comparison of Canada and the United States
}

John A. Turner

AARP Public Policy Institute

Follow this and additional works at: https://research.upjohn.org/empl_research

Part of the Labor Economics Commons

\section{Citation}

Turner, John A. 2001. "Risk Sharing through Social Security Retirement Income Systems: A Comparison of Canada and the United States." Employment Research 8(4): 5-6. https://doi.org/10.17848/

1075-8445.8(4)-2 
W.E. Upjohn Institute for Employment Research

Employment Research - October 2001

John Turner

\section{Risk Sharing through Social Security Retirement Income Systems}

\section{A Comparison of Canada and the United States}

Workers bear risk through variations in compensation due to changes in wage and nonwage compensation, the hours and tenure on their job, and benefits from government labor market programs. Insights about worker risk-bearing can be gained through comparisons of the Canadian and U.S. labor markets, which is the topic of a recently published Upjohn volume (Turner 2001). Labor markets in the two countries have many similarities (such as facing the aging of the baby- boom generation) and many interconnections (they exchange more goods and services than any other two countries in the world). The social security old-age benefit programs in Canada and the United States provide social insurance that reduces risk bearing by workers and are one aspect of the pattern of risk-bearing in the two countries. Perhaps because of societal differences concerning the role of government, the Canadian and U.S. programs differ in ways that affect the amount of risk-bearing they provide.

While most analyses of retirement benefits focus on the expected level of pension benefits, or on their rate of return or internal rate of return, the riskiness of retirement benefits and their risk-bearing aspects are also important to workers. A simple measure of the riskiness of retirement benefits is the variability in their real value. This measure is affected by factors influencing the accrual of real pension benefits up to retirement (primarily wages and hours worked) and by factors affecting the variability in the real value of benefits once benefit payment has started, which is tied to the indexation of the benefits for inflation.

The simple measure of risk is inadequate because financial theory indicates that risk can be considered only in the context of the total portfolio held by the retiree or worker. The correlation of pension risk with other risks the worker faces should be considered. When retirement benefit risks are positively correlated with job risks, the effects of retirement benefit risks are more serious. When retirement benefit risks offset job- related risks, the variability in retirement benefits plays an insurance role.

The primary income-producing asset of most workers is the human capital associated with their job, which often has risks that are positively correlated with the risks of an occupational pension plan (if one is provided). Traditional defined- benefit pension plans tend to reward longevity on a job, and thus any factor that increases the risk of losing one's job also adversely affects the value of the pension. Social security, however, is an important part of the wealth portfolio of most workers and is often structured so as to offset job-related risks, for example, by allowing workers to exclude periods of low earnings when calculating benefit levels. 


\section{Risk Bearing in Retirement Income Systems}

Social security benefits in both Canada and the United States are provided by traditional defined-benefit plans that determine benefits by applying a formula to the worker's years of service and earnings. In structuring social security systems, a tradeoff occurs between providing incentives and providing risk- bearing. When social security benefits are perfectly tied to wages, as in an individual account plan that bases contributions on wages, no risk-bearing is provided, but rather the risks in terms of the level of benefits are correlated with job risks. Risk-bearing in social security can be provided by a defined-benefit plan by making the benefit formula or the tax support progressive. Income redistribution can be considered an aspect of risk-bearing concerning risks to one's labor market earnings.

\section{Canadian-U.S. Comparisons}

Risk-bearing concerning future retirement income in the Canadian and U.S. social security systems can be compared along various aspects of retirement income risk, such as:

- $\quad$ wage risk due to unanticipated changes in the worker's wages,

- $\quad$ early retirement risk due to unanticipated changes in the age at which the worker retires,

- $\quad$ longevity risk due to the uncertainty as to date of death,

- demographic risk due to unanticipated changes in population age structure,

- $\quad$ inflation risk due to unanticipated changes in the price level,

- $\quad$ political risk due to unanticipated changes in taxes and the benefit formula, and

- $\quad$ financial market risk due to unexpected fluctuations in asset prices.

While demographic risk is often the focus of discussions, age structure changes due to fertility are completely known once a cohort has been born, and, from that point, the major risks are due to immigration and mortality changes.

Table 1 shows calculated replacement rates provided by social security to workers at different levels of preretirement earnings. Compared with the United States, social security benefits in Canada are more progressive, being more generous for low-income workers and less generous for high-income workers.

Not taken into account in the standard measures of progressivity, both the Canadian and U.S. social security systems allow workers to exclude some low earnings years when determining benefits. For workers suffering a loss in earnings, this provision protects their social security benefits from being reduced by that loss.

In the United States, for workers with more than 35 years of earnings, social security excludes their lowest years when calculating benefits. Thus, someone starting at age 18 and working to 62 would have 44 years of work and 9 dropout years; someone starting at age 22 would have 40 years of work and 5 dropout years. 
Table 1 Income Replaced by Social Security in the United States and Canada (U.S. \$)

\begin{tabular}{cccc}
\hline $\begin{array}{c}\text { Individual's } \\
\text { earnings } \\
\text { preretirement } \\
(\$)\end{array}$ & $\begin{array}{c}\text { Old-age benefit } \\
\mathbf{( \$ )}\end{array}$ & $\begin{array}{c}\text { U.S. } \\
\text { replacement rate } \\
(\boldsymbol{\%})\end{array}$ & $\begin{array}{c}\text { Canadian } \\
\text { replacement rate } \\
(\%)\end{array}$ \\
\hline 0 & 0 & NA & NA \\
6,450 & 5,087 & 79 & 130 \\
12,900 & 7,346 & 57 & 71 \\
19,350 & 9,606 & 50 & 51 \\
25,800 & 11,868 & 46 & 42 \\
51,600 & 13,764 & 27 & 21 \\
129,000 & 13,764 & 11 & 8 \\
\hline
\end{tabular}

${ }^{\mathrm{a}}$ The old-age benefit calculation assumes the worker retired at 65 in 1994 with average indexed annual earnings shown in the left-most column.

SOURCE: Gunderson, Hyatt, and Pesando (1996).

In Canada, full-career workers eventually will be able to exclude their seven lowest years of earnings (or 15 percent of their working years, whichever is lower, counting all years from age 18 to age 65), in calculating benefits. Thus, for current lower-income workers who start working at 18 and retire at 62, the Canadian system provides fewer dropout years than does the U.S. system (6.6 vs. 9), providing less protection against periods of low earnings. For someone starting work at 22, the pattern is reversed with respect to the United States (6 vs. 5).

Survivor's benefits are more generous in Canada than in the United States for women who have worked but less generous for women who never worked outside the home. In Canada, a surviving wife continues to receive her Old Age Security benefit, while that of her husband ends at his death. Thus, she receives 50 percent of the benefits they both received while her husband was alive. In addition, she receives 60 percent of the Canada Pension Plan benefit of her husband. She thus receives less than 60 percent of their joint benefits. A U.S. woman who had never worked outside the home would receive 67 percent of the joint benefit received by herself and her husband while he was alive. Indexation of benefits provides insurance against inflation during retirement. The United States provides full annual price indexation of benefits starting at retirement. Canada provides quarterly indexation of benefits for Old Age Security benefits. When inflation is low, the difference between quarterly and annual indexation is unimportant, but in periods of high inflation, Canada provides better protection against inflation than does the United States.

The progressivity of a retirement income system is affected both by the structure of benefits and the structure of taxes used to finance the benefits. The exclusion of the first Can $\$ 3,500$ of earnings from social security payroll taxes is a progressive feature of the Canadian tax support for social security that is not present in the United States. Also, Canada finances 
roughly one-third of old-age benefits through general revenues. General revenues, primarily from personal income taxes, are a more progressive source of taxes than are social security taxes because of the higher tax rates that apply to higher earners. Thus, overall it appears that the Canadian system is more progressive in its tax structure that supports social security financing.

\section{Conclusions}

While in some ways the U.S. system provides greater protection against risks, overall it seems the Canadian system provides greater insurance against income risks through the greater progressivity of its financing and benefits. For most women, it provides more generous survivor's protection, but it provides less generous protection for widows who have not worked.

John A. Turner works in the Public Policy Institute of AARP.

\section{Suggestions for further reading}

Gunderson, Morley, Douglas Hyatt, and James E. Pesando. 1996. "Public Pension Plans in the United States and Canada." Prepared for the W.E. Upjohn Institute Conference on Employee Benefits, Labor Costs, and Labor Markets in Canada and the United States, November 4-6, 1994.

Turner, John A., ed. 2001. Pay At Risk: Compensation and Employment Risk in the United States and Canada. Kalamazoo, Michigan: W.E. Upjohn Institute for Employment Research. 